\title{
H1-2 wt Allele
}

National Cancer Institute

\section{Source}

National Cancer Institute. H1-2 wt Allele. NCI Thesaurus. Code C162854.

Human H1-2 wild-type allele is located in the vicinity of $6 p 22.2$ and is approximately $1 \mathrm{~kb}$ in length. This allele, which encodes histone $\mathrm{H} 1.2$ protein, is involved in chromatin wrapping. 